\title{
A METHOD TO INCREASE IS ENROLLMENTS
}

\author{
Kevin Lee Elder, Georgia College \& State University, Kevin.Elder@GCSU.edu \\ Tanya Goette, Georgia College \& State University, Tanya.Goette@GCSU.edu \\ Ron MacKinnon, Georgia Southern University,rmackinn@georgiasouthern.edu
}

\begin{abstract}
SAP is fairly widely used in the undergraduate business curriculum, but what effect does it have on the IS enrollment? This paper describes how any university would be able to incorporate SAP into their curriculum and the positive effect it has had on our enrollment, showing results from not one but two universities. SAP has a University Alliance program that encourages universities all over the world to cooperate in the use of SAP in the curriculum. SAP maintains an SAP University Alliance Community web page that lists major SAP applications developed by various universities and these applications are made available to all members of the SAP University Alliance. In these times of shrinking budgets and tight employment opportunities for business school graduates we found results to suggest that many universities should be considering using SAP in the curriculum. Our paper will be a guidebook or framework for how to accomplish that.
\end{abstract}

Keywords: IS Pedagogy, IS Curriculum, ERP, Analytics

\section{INTRODUCTION}

Since 2001, enrollment in information systems programs around the nation and the world have plummeted (George, Valacich and Valor 2005; Granger et al., 2007; Scott et al. 2009) and remains low despite positive job market predictions (United States 2008 -2009; Weis, 2009). Research has also shown that Information Systems is among the least preferred majors (Lee and Lee, 2006). Research has also shown that possible majors perceive that information systems is a job that entails sitting at a computer all day doing hard uninteresting, boring and difficult work (Dick et al.,2007; Walstrom et al. 2008; Scott et al., 2009). Dick et al (2007) also found that possible majors believe that opportunities in the information systems field are limited and shrinking due to offshoring and outsourcing. And furthermore, information systems programs have historically done an ineffective job marketing the major to possible majors, their parents, advisors and counselors who have limited knowledge of the major or the expanding career opportunities (Walstrom et al. 2008). We believe that programs need to show both possible employers and possible majors that the major is indeed a viable and preferred business major. The introduction of business processes and enterprise resource planning topics throughout the curriculum is a strong method to stem the tide of declining enrollments by giving the students a toolset that is in high demand in industry and in short supply.

Enterprise Resource Planning (ERP) software is software that runs entire companies like Coca Cola or Home Depot and this kind of software runs most of the big companies in the world. The leading ERP company is SAP, which is the world's largest software company. SAP employs more than 51,500 in more than 50 countries, is used in more than 120 countries and the SAP software is available in more than 40 different languages. Because SAP is such a large company with their software widely adopted all over the world, SAP is constantly in need of additional people who know how to use SAP software.

There has been quite a bit written and published concerning introducing and using SAP in the undergraduate information systems programs (Andera, F. \& Derringer, D. W., 1998; Hawking, P., Ramp, A. \& Shackleton, P., 2001; Hawking, P., McCarty, B. \& Stein, A., 2004; Abdinnour-Helm, S. \& Chapman, B., 2006; Boyle, T., 2006; MacKinnon, R., K.L. Elder,2009; MacKinnon, R., K.L. Elder, H.J. Kung, 2010; Kung, HJ., R. Mackinnon, K.L. Elder, 2010). Since 1999 there has been an increase in articles written about expanding the use of SAP across the undergraduate business degree (Gust, D. D. \& Hayen, R. L., 1999; Corbitt, G. \& Mensaching, J., 2000; MacKinnon, R., 2004; Andera, F ., 2004; Andera, F. \& Hayen, R., 2006A; Andera, F. \& Hayen, R., 2006B). We have found no articles discussing the use of SAP in the curriculum as a tool to offset declining enrollments besides the one we 


\section{Issues in Information Systems \\ Volume 20, Issue 4, pp. 137-146, 2019}

authored (K.L. Elder, R. MacKinnon, H.J. Kung, 2010). We are building off that work to discuss the latest addition to our offerings at Georgia Southern.

\section{SAP University Alliance (SAPUA)}

In order to have a continuing supply of educated university graduates knowledgeable about SAP software, SAP created an association with universities called the SAP University Alliance (SAPUA). SAP Education Alliances are designed to:

- Develop graduate and undergraduate learning programs that enable teaching and understanding of

- integrated business processes

- Encourage technically sophisticated graduates who can apply SAP solutions and technology to

- pursue careers in real-world business environments

- Create a network of university researchers who contribute to the body of knowledge and

- innovative applications of SAP solutions

- Provide the needed resources to help ensure a successful integration of SAP into the classroom,

- including curriculum materials and functional experts (Source: SAP Website:

- http://www.sap.com/usa/company/citizenship/education/index.epx).

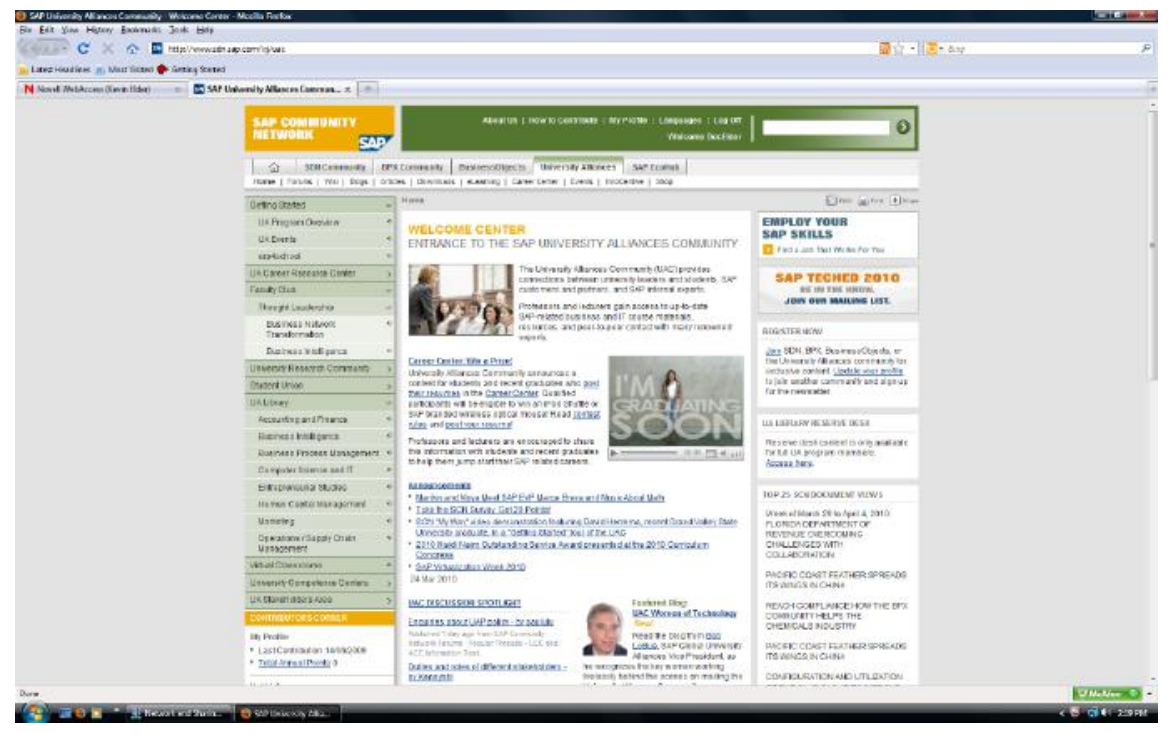

Figure 1. SAP University Alliance Welcome Page.

As you can see from Figure 1, SAPUA members benefit from access to:

- A collaborative global network

- Professional development, research, and industry collaboration

- Forums, blogs, and Wikis

- Articles

- Curricula development workshops and events

- Curriculum materials.

Faculty members at SAPUA member institutions can click on the Library tab and view curriculum material from other member institutions as depicted in Figure 2 and 3. Faculty can attend SAP-sponsored workshops and SAP customer training classes at no cost. Faculty at SAPUA member schools also access to information on SAP events, research, and downloadable curriculum materials all throughout the year and as you can see it is not limited to information systems topics. You can find curriculum material right off the library page for:

- Accounting

- Business Intelligence

- Finance 


\section{Issues in Information Systems}

Volume 20, Issue 4, pp. 137-146, 2019

- Business Process Management

- Human Capital Management

- Marketing Management

- Supply Chain Management, Manufacturing and Production

- Operations Management

- Computer Science, Technology and Information Systems.

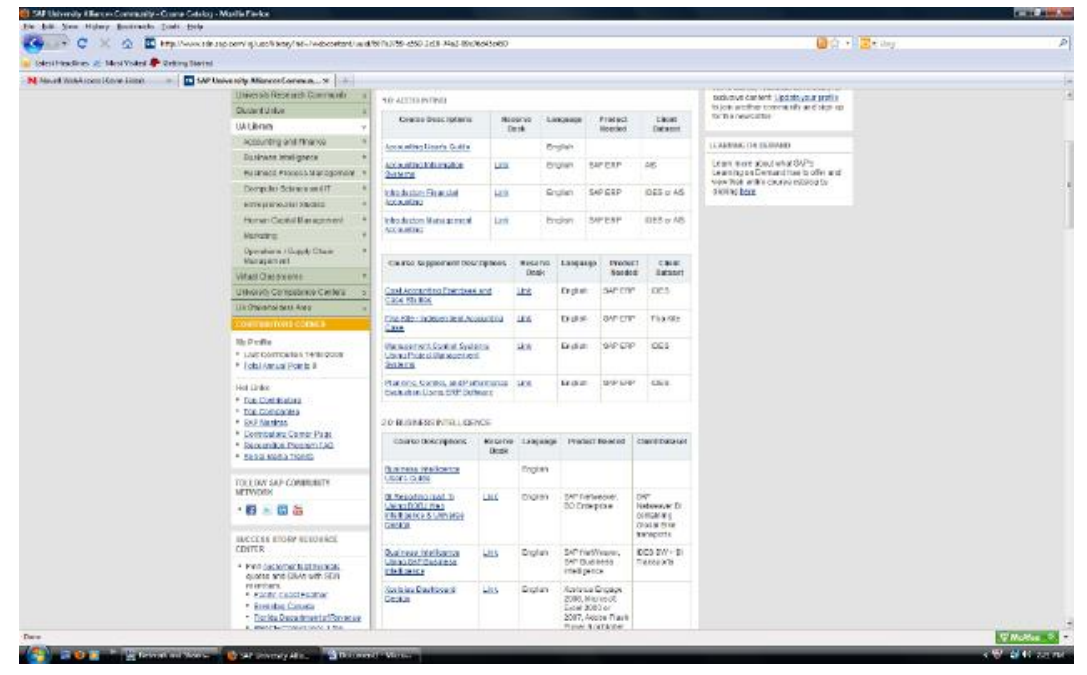

Figure 2. Accounting, Finance and Business Intelligence Curriculum Material

On this web page there are more than 59 applications in these various areas. Many of the applications that the SAP University Alliance makes available to universities are being incorporated into undergraduate business programs and could be incorporated into the MBA curriculum as well. For example, if a university wanted to incorporate an introduction to ERP in their curriculum the Global Bike application includes SAP navigation, a SD (sales and distribution) case study, a MM (materials management) case study, a PP (production planning) case study, a FI (financial accounting) case study, and a CO (managerial accounting) case study. These applications are fully documented and include step by step instructions on how to complete the SAP application. As an added bonus, any university that has a $30 \%$ SAP content in 3 courses can offer an SAP certificate to their students. Fees for annual program membership vary by country. In the U.S., the current annual SAPUA membership fee is $\$ 8,000$.

SAPUA membership can be a focal point for university program differentiation and distinction. It has the potential to improve student recruiting, to enhance the university's reputation, and to improve the marketability of its graduates. It may also assist in attracting educators whose primary interests lie in enterprise systems and integrated business process solutions (MacKinnon, R., K.L. Elder,2009; K.L. Elder, R. MacKinnon, H.J. Kung, 2010).

For students, SAP's University Program provides a vehicle for gaining hands-on experience with SAP solutions. Those that graduate with UA certification increase their chances of finding employment with SAP user organizations via clicking on the student union tab from the welcome page (Figure 1), they will be taken to Figure 4. From this site they can post their resumes, view open SAP positions, learn more about further SAP education and training opportunities and more. The SAP certification is rapidly becoming one of the most useful certifications and students can earn one from your university by taking a minimum of three SAP courses at an SAP University Alliance member institution. These courses are not limited to information systems courses and as you can see from the few examples shown here, almost all of your MBA courses could be SAP courses.

From Figure 1 you can see that there is so much more that the SAP program has to offer your faculty, from articles, to forums, to research opportunities too numerous to mention in this paper. Simply go to the SAPUA site for much more information (www.sdn.sap.com/irj/uac). 


\section{Issues in Information Systems}

Volume 20, Issue 4, pp. 137-146, 2019

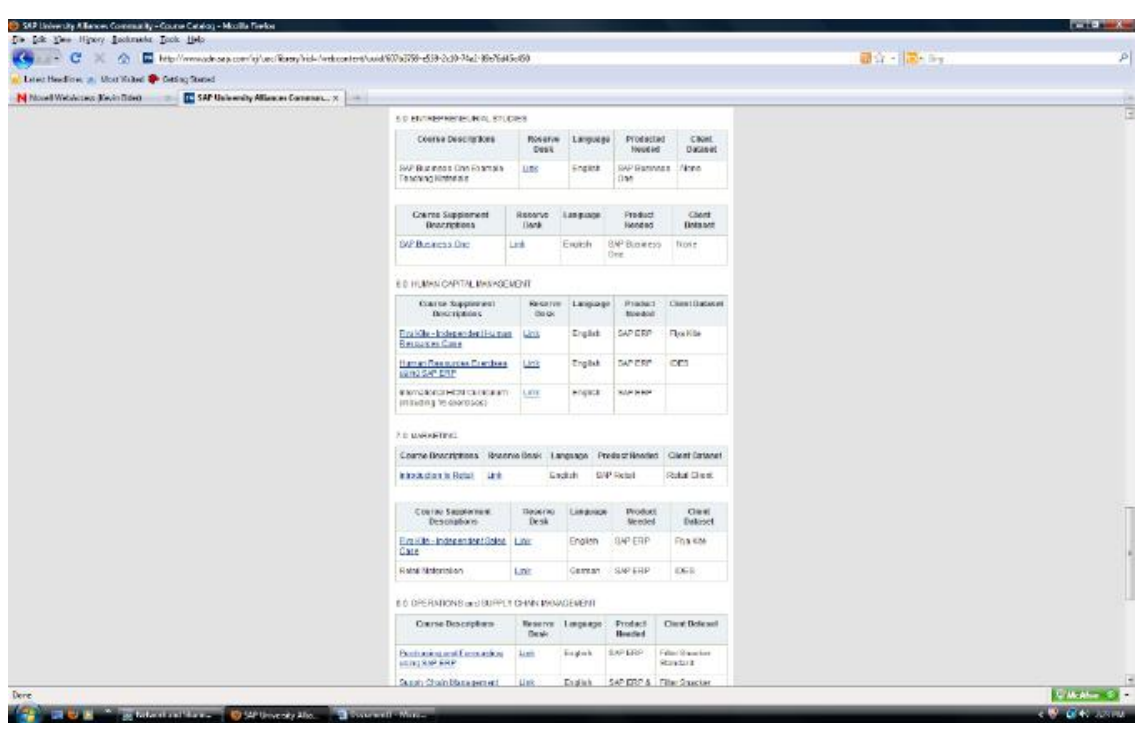

Figure 3. Entrepreneurial, Human Capitol, Marketing Curriculum Material

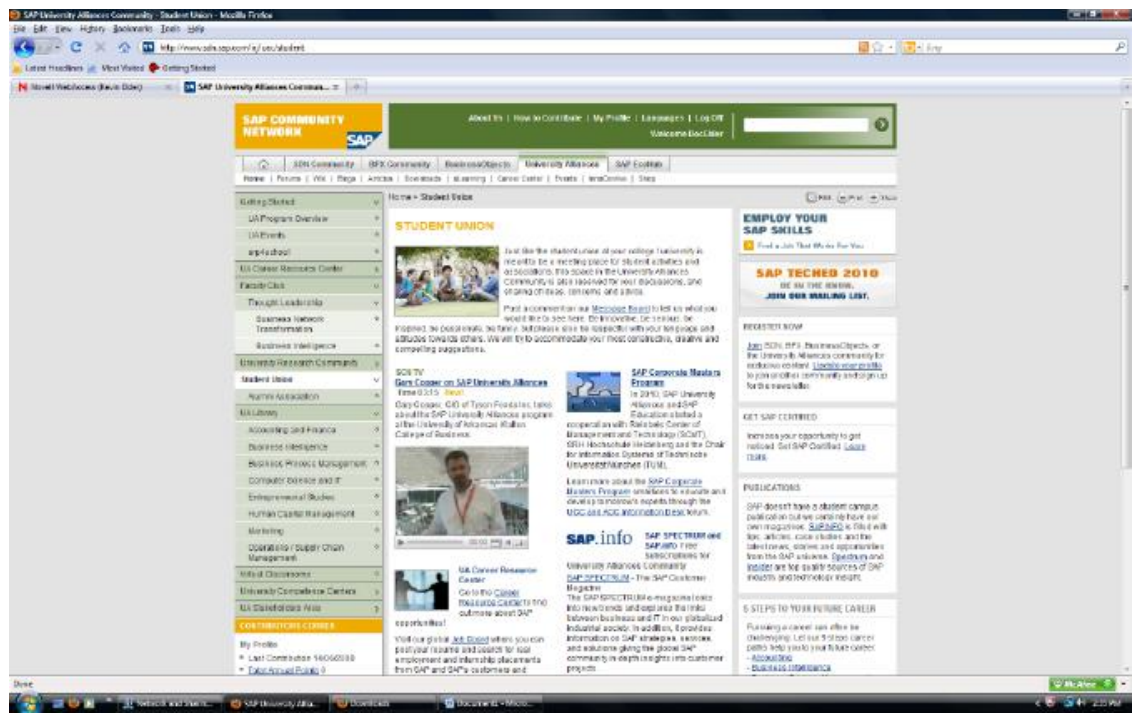

Figure 4. Student Union Page for students

Another benefit of the SAP University Alliance program is the fact that they provide University Competence Centers (UCC). These UCCs not only host the SAP software for the member institutions, they also provide technical support. While Information Systems faculty may not need this support very often, the non-technical oriented faculty in other disciplines will find this a valuable resource bundles in with their membership. This makes the entire program more accessible to other disciplines as we outlined for a typical MBA program.

An article (Feb., 2007) in NetworkWorld, titled "SAP Workers in High Demand," states: "A shortage of skilled SAP workers is making it difficult for IT departments to fill open jobs and caused the average salary for certain high-level SAP professionals to rise $15.6 \%$ in the past year... the average base salary for directors of SAP program management rose from $\$ 115,468$ to $\$ 133,500$ in the calendar year that just ended. This increase of $15.6 \%$ dwarfs the typical increases in IT salaries of 3\% to 5\% a year, says David Foote, CEO and chief research officer." 


\section{EFFECT ON IS ENROLLMENTS AT GEORGIA SOUTHERN UNIVERSITY}

Figure 5 graphically depicts what has happened to IS enrollments 2006 to 2012 at University One. SAP had been taught prior to 2006 but it was in the 2006 to 2007 time frame that a greater emphasis in the department was placed on SAP. Students entering the business school at Georgia Southern are required to take the Introduction to Business class. Faculty from the IS department started going into these courses and advertising SAP as an option for introduction to business students to help them get jobs from fortune 500 companies.

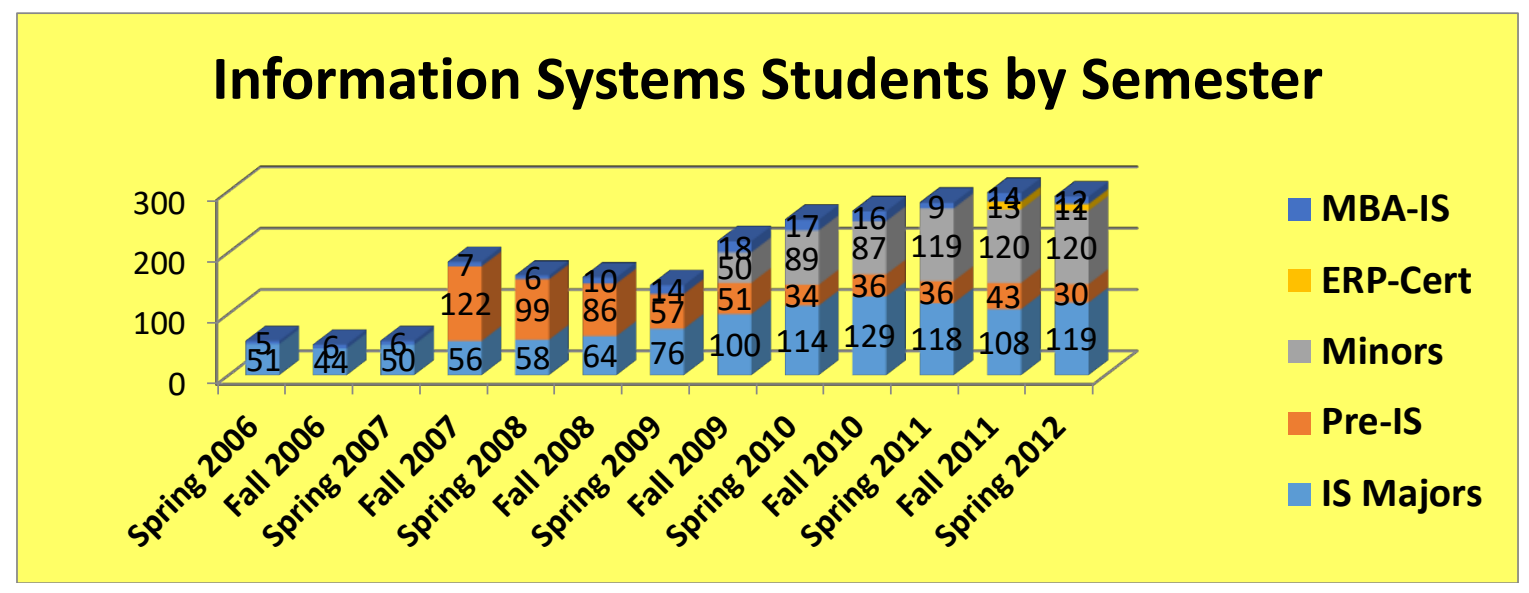

FIGURE 5. IS Enrollments at Georgia Southern University

Once news of the SAP certification, for taking three SAP courses, was advertised you can see the jump in pre-is majors (freshman and sophomores) declaring their intent to major in IS and the subsequent jumps in IS enrollment. Starting in Fall of 2009 the option to minor in IS (with SAP courses and certification) was implemented you see the second obvious increase in IS enrollments. And all of this is in a time where programs like Central Florida are closing down there is programs, and most everyone else is struggling to stem the tide of diminishing enrollments.

Starting in the Fall of 2011 Georgia Southern University began offering a graduate certificate in ERP, using SAP. This was done in response to so many people who had graduated with bachelor's degrees and did not want a bachelor's in IS or a minor in IS in another bachelor's degree. This program is taught entirely online and will be another jump in enrollment for the IS department in 2012 and beyond. The ERP Certification course is a capstone experience that covers in detail the core modules of SAP's ERP (Enterprise Resource Planning) application, which has been designed to support the core business operations of organizations seeking state-of-the-art business processes. The course also includes SAP ERP analytical and reporting functions. On the last day of the course, the C_TERP10_60 certification exam is administered. Students who pass the exam are added to SAP's database of certified practitioners. SAP is actively promoting the C_TERP10_60 certification as a strategy to ameliorate the SAP skills shortage that exists within the industry.

Table 1. SAP Jobs Listed on Major Web Sites Used by Employers Recruiting SAP Talent

\begin{tabular}{|c|c|c|c|}
\hline $\begin{array}{c}\text { Number of } \\
\text { Listed SAP } \\
\text { Jobs }\end{array}$ & SAP Jobs in GA & Web Site & URL \\
\hline 47,368 & 1,690 & Indeed.com & http://www.indeed.com \\
\hline 22,844 & 1,062 & SAPJob.net & http://www.sapjob.net/ \\
\hline 8,205 & 406 & Dice.com & http://www.dice.com \\
\hline 8,831 & $\begin{array}{l}423 \text { new postings } \\
\text { in last } 30 \text { days }\end{array}$ & CareerBuilder.com & http://www.careerbuilder.com \\
\hline 2,478 & 1,486 & $\begin{array}{l}\text { SAP Community Network } \\
\text { Career Center }\end{array}$ & $\begin{array}{l}\text { http://scncareercenter.jobtarget.com/home/index. } \\
\text { cfm?site id }=8446\end{array}$ \\
\hline
\end{tabular}


The existence of a skills gap is easily verified by job sites for IT professionals. The following table summarizes the results of recent searches for SAP jobs on major Web sites used by employers to recruit SAP talent.

The demand for employees with SAP skills is sufficiently strong to support specialized Web sites including: SAPJob.net, SAP Community Network Career Center, SAPCareers.com, SimplySAP.com, and JustSAPJobs.com. SAP job listing also dominate sites such as erpCareer.com and ERP-Consulting.com.

SAP Certifications, such as that attained by passing the TERP10 certification exam, are sought by many employers seeking new employees. Jeffrey Word (Word, 2009), Vice President of Product Strategy for SAP AG states that "TERP10 Certification is the equivalent of $\$ 10,000$ in starting salary." Based on the volume of external inquiries, current enrollments in graduate courses with SAP components, persistent SAP talent shortages among employers, and salary differentials associated with SAP Certification, we estimate that at least 25 students will enroll in the ERP Certificate program each year.

The addition of this certificate program is likely to increase student interest in the university's MBA, MAcc, and MS in Applied Engineering (IT Emphasis) programs. Prospective students are likely to perceive the ERP Certificate as an attractive add-on for these degrees. It may also increase student interest in the WebMBA program. For some students, the ERP Graduate Certificate program is likely to serve as a stepping stone to the university's MBA, MAcc, and MS in Applied Engineering (IT Emphasis) programs. A student enrolled in the ERP Certificate program who earns a B in each of the courses taken could use multiple courses toward each of these degrees.

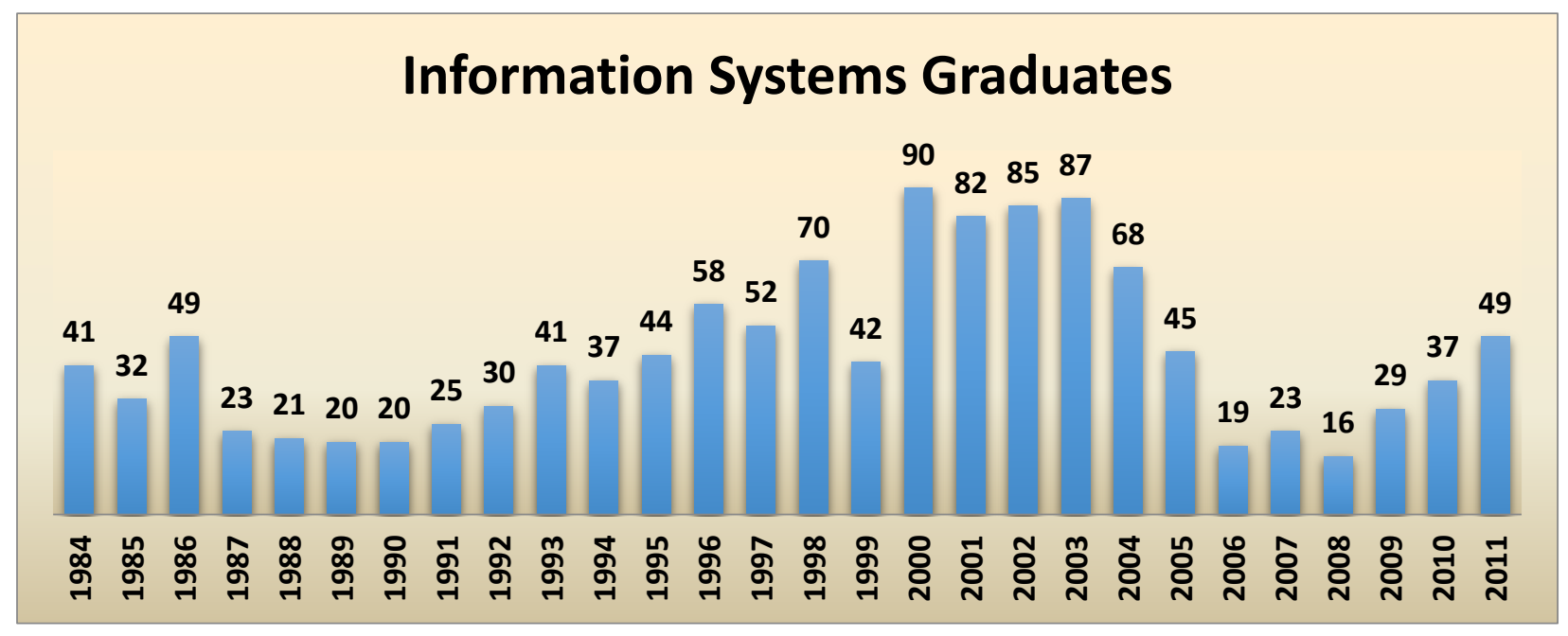

Figure 6. Georgia Southern University Information Systems Graduates

Finally we take a quick look at the graduates from the IS program since its' inception in Figure 6 and you see the down turn in graduates starting in 2000, like we have seen in almost every program across the nation. After the implementation of the programs and the SAP emphasis you see the tide stemmed in graduates just like you saw in the enrollments in Figure 5.

\section{EFFECT ON IS ENROLLMENTS AT GEORGIA COLLEGE \& STATE UNIVERSITY}

Was this effect on IS Enrollments a one off and not repeatable? The answer is no. At Georgia College \& State University they hired away a key architect of Georgia Southern's emphasis in ERP in 2013. Georgia College \& State University decided to change their curriculum away from programming and to emphasizing Enterprise Systems and Analytics. Georgia College \& State University was a smaller campus than Georgia Southern University, so shifts and gains can be expected to be a little more significant in percentages but not in raw numbers. 


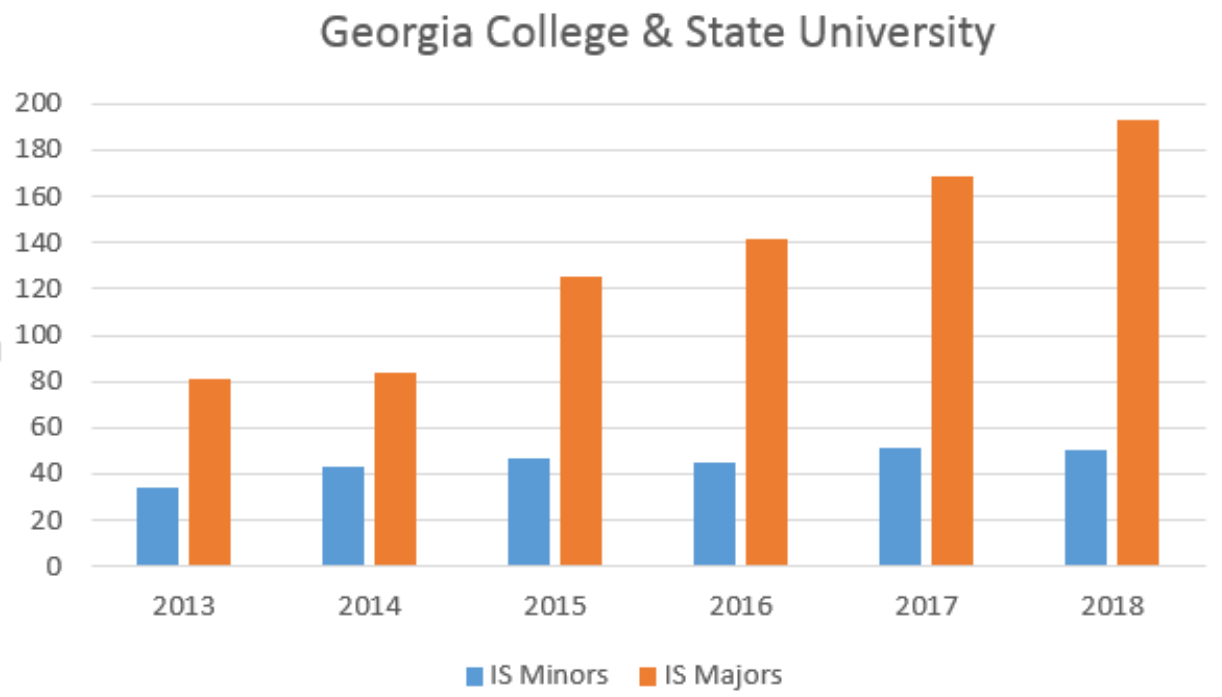

Figure 7. Information Systems Majors and Minors

As you can see in Figure 7, from 2013 to 2018 the increase in majors and minors at Georgia College \& State University coincided with the implementation of the new ERP \& Analytics curriculum that was announced in 2015, juniors (majors \& minors) started taking the new courses in 2016 and seniors graduated in 2017. While minors are limited by space in the junior sections of MIS classes we did not see the same growth in minors as was seen at Georgia Southern. If space in the classes were not an issue we would have seen similar growth in minors. Majors have experienced a more dramatic growth over the years from 2015 through 2018. It must be noted that since the university did not grow in size that this shift to larger numbers of IS majors means they shifted from other majors on campus who now saw the MIS program as more desirable than it had been in the past. In the field of Analytics there has been a shift towards non-programming. While there is still a need for Data Scientists, there is an ever increasing role for so-called Citizen Data Scientists, or Data Analysts, or simply Business Analysts and these programs built from the SAP University Alliance program can grow quite nicely in current times.

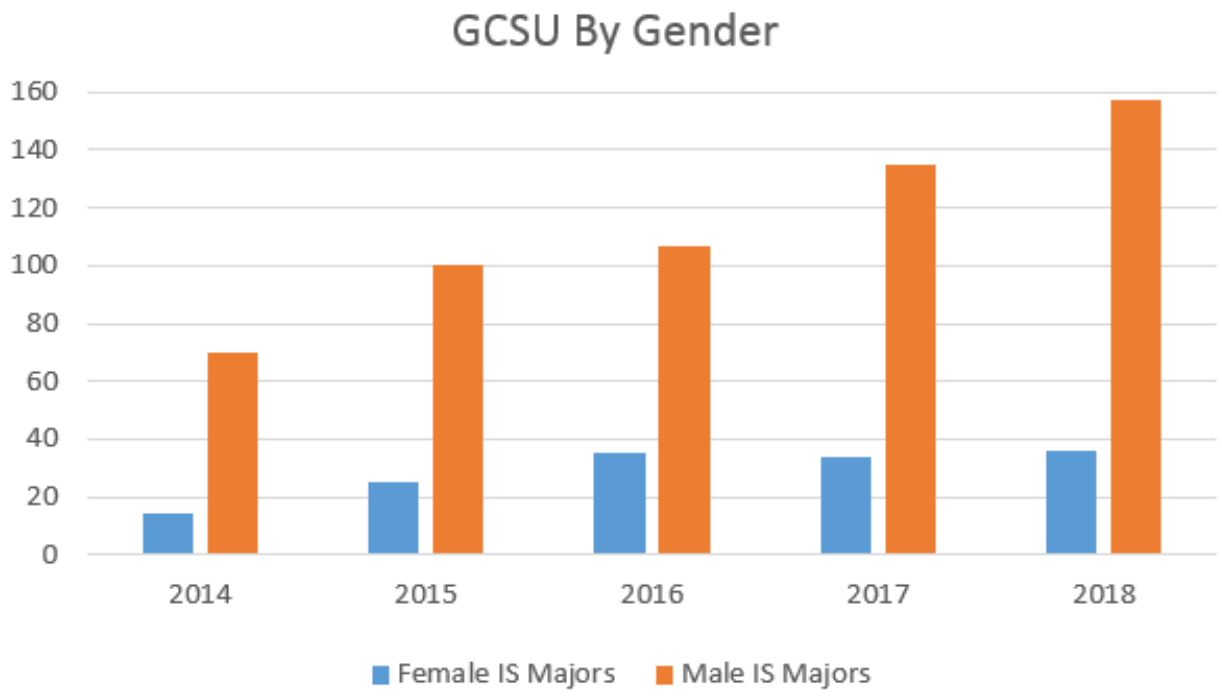

Figure 8. All Information Systems Majors by Gender 


\section{Issues in Information Systems}

Volume 20, Issue 4, pp. 137-146, 2019

Another interesting aspect of the implementation of the new curriculum at Georgia College \& State University is that the female numbers have increased as depicted in Figure 8 and Figure 9. This phenomenon was not witnessed at Georgia Southern University. While the number of IS majors has grown to more than double, the female numbers have grown to nearly triple and would be higher if we had the numbers from minors, but all we have are gender breakdowns for majors. At Georgia Southern University there was no reduction in the number of programming classes and there was no increase in the number of females in the programs. As the growth in numbers was almost all males choosing the programs. While at Georgia College and State University there has been a growth from around 16 percent female majors in 2014 to around 25 percent in 2016, which is quite a turnaround and leads to more diversity and inclusion. In raw numbers of female MIS majors we have a more than doubling and expect to hit a tripling of female majors in the coming year from raw numbers in 2014. And when you look at the Senior MIS majors in Figure 9, the percentage of females show a growth from 2 or 3 females in 2014-5 ( 10\%) to 10 to 11 females in 2016-8 (20-27\%) in the new not so technical courses in the major with more interesting job possibilities.

\section{Female \% of Senior MIS Majors}

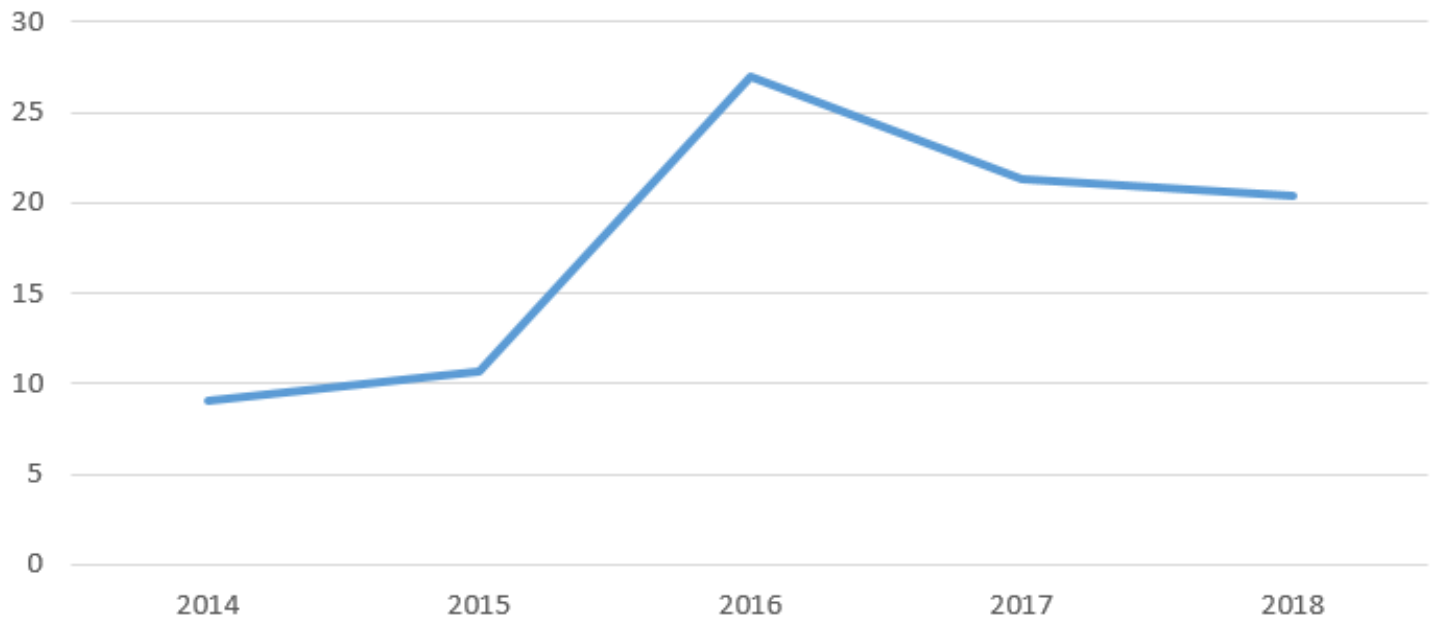

Figure 9. Senior Class Information Systems Majors Percent Female

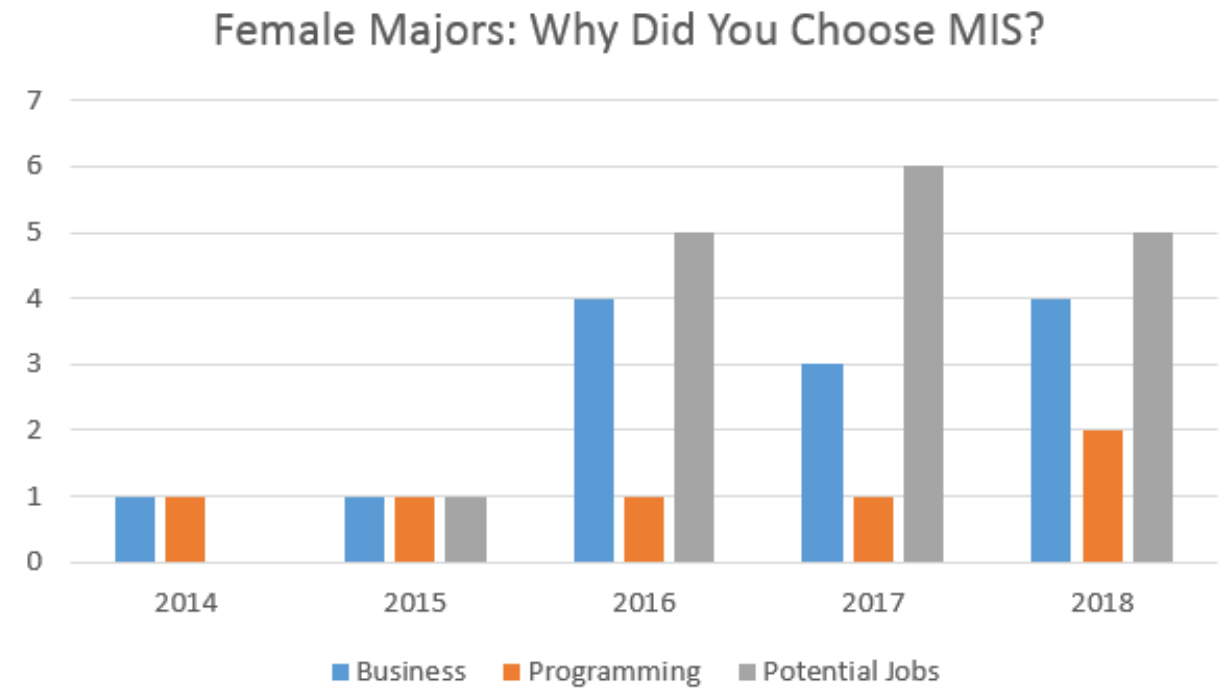

Figure 10. Survey Question for Senior Class Female Majors: Why Did You Choose MIS? 


\section{Issues in Information Systems}

Volume 20, Issue 4, pp. 137-146, 2019

The students were given a survey question in their Fall Semester Senior MIS course, 'Why did you choose MIS?' As you can see in Figure 10, in 2014 the programming/technical aspect and the fact it was a business degree were the deciding factors. However, with the new curriculum and larger numbers of female majors the programming and technical side is still low while the potential for good jobs has seen a $500-600 \%$ increase! These percentages in 2019 are far from ideal in that we still need a higher percentage of female majors, but the numbers are definitely going in the right direction. So why would your university not try this approach?

\section{SUMMARY}

A university looking for something new to offer that could attract new students to your MIS or IS programs should seriously investigate the SAP University Alliance and offering at least some of the courses mentioned above. The SAP curriculum resources made available through the University Alliance program could and should be used in the graduate program as well. Companies are constantly looking for new hires with SAP experience, combine that with your MBA degree and you have a lethal combination. Given the high demand among SAP user and consulting organizations for TERP10 certified employees, we anticipate that the creation of this program will have minimal impact on enrollments in these existing programs. Similarly, we do not expect these existing programs to have a detrimental impact on our Graduate ERP Certificate program. Online delivery of this certificate program with asynchronous courses will improve accessibility to quality graduate education across the state as well as to students across the nation and around the world. The two-week ERP Certification course will be the only component of the ERP Graduate Certificate that will not be delivered online.

Georgia College \& State University and their emphasis on Analytics and Citizen Data Scientist also poses a possible solution to the gender issues plaguing all STEM majors in the US. If the sustained growth in females in raw numbers continue we will eventually see a growth in the percentage of female MIS majors as well. Diversity in the STEM fields is important and identifying ways to attract them is a worthwhile result to investigate and research more as it was result we were not anticipating directly but had hoped for. For universities just considering the implementation of SAP in their curriculum, we hope this paper can be used as a guide for how you might proceed.

\section{REFERENCES}

Abdinnour-Helm, S. \& Chapman, B. "A Usability Study of SAP R/3 in a Course on Enterprise Resource Planning”, Proceedings SAP Curriculum Congress '06, 2006, 25.

Andera, F. (2004). Salary Comparison of Central Michigan's College of Business Administration Graduates Who Have and Have Not Taken SAP R/3 Supported Classes. Issues in Information Systems, 1, 8-14.

Andera, F. \& Derringer, D. W. (1998). SAP: Implications for Computer Information Systems. Journal of Computer Information Systems, 19(1), 72-75.

Andera, F. \& Hayen, R. (2006A). Moving a College of Business Core Curriculum to the Next Level in SAP Enterprise Software Curriculum Integration, Proceedings SAP Curriculum Congress '06, 14.

Andera, F. \& Hayen, R. (2006B). Directions in SAP Enterprise Software Integration in Business Curricula, Proceedings SAP Curriculum Congress '06, 23.

Antonucci, Y. L. Corbitt, G. Stewart, G. \& Harris, A. L. (2004). Enterprise Systems Education: Where Are We Going? Journal of Information Systems Education, 15(3), 227-234.

Boyle, T. (2006). An Enterprise Resource Planning Major for Computing and Information Systems Students, Proceedings SAP Curriculum Congress '06, 22.

Corbitt, G. \& Mensaching, J. (2000). Integrating SAP R/3 into a College of Business Curriculum: Lessons Learned. Information Technology and Management, 1(4), 247-258. 
Dick, G., Granger, M., Jacobson, C. \& VanSlyke, C. (2007). Where Have All the Students Gone? Strategies for Tackling Falling Enrollment. Proceedings of the Americas Conference on Information Systems, Keystone $\mathrm{CO}$.

Elder, K. L., MacKinnon, R., \& Kung, H. J. (2010). SAP in the MBA Curriculum, SOBIE.

George J.F., J.S. Valacich, \& Valor, J. (2005). Does Information Systems Still Matter? Lessons for a Maturing Discipline. Communications of the Association for Information Systems, 16(8), 219-232.

Granger, M. J., Dick, G., Luftman, J., Van Slyke, C., \& Watson, R. T. (2007). Information System Enrollments: Can They Be Increased? The Communications of the Association for Information Systems, 20(41), 649-659.

Gust, D. D. \& Hayen, R. L. (1999). Including SAP Enterprise Software in the Introductory Business Computer Course, Proceedings, ISECON, October.

Hawking, P., Ramp, A. \& Shackleton, P. (2001). IS '97 Model Curriculum and ERP Systems. Business Process Management Journal, 7(3), 225-233.

Hawking, P., McCarty, B. \& Stein, A. (2004). Second Wave ERP Education. Journal of Information Systems Education, 15(3), 327-332.

Kung, H.J., MacKinnon, R., \& K.L. Elder. (2010). ERP Simulations. SOBIE.

Lee, Y. \& Sang J. L. (2006). The Competitiveness of the Information System Major: An Analytic Hierarchy Process." Journal of Information Systems Education, 17(2), 211-221.

MacKinnon, R. (2004). Integration of ERP in the Business Curriculum. Issues in Information Systems, 413-419.

MacKinnon, R., Kevin, L. E. (2009). Innovations for Business Schools and IS Depts. SOBIE.

MacKinnon, R., Kevin, L. E., Kung, H. J. (2010). SAP Certifications. SOBIE.

Networkworld. (2007). SAP Workers in High Demand, Retrieved from: http://www.networkworld.com/news/2007/021207-sap-workers.html

SAP Americas: Our Role in the World's Largest Software Company, http://www.sap.com/usa/about/index.epx

Scott, Ch. "Kit", Fuller, M., Kimberly M. MacIndoe, \& Josh. K. D. (2009). More Than a Bumper Sticker: The Factors Influencing Information System Career Choices. Communications of the Association for Information Systems, 24(2), 7-26.

United States. (2009). Occupational Outlook Handbook, 2008-09 Edition, Computer and Information System Manager. Bureau of Labor Statistics, United States Department of Labor, Accessed: January 19, 2009. http://www.bls.gov/oc/ocos258.htm

Walstrom, K. A., Schambach, T. P., Keith T. J., \& Crampton. W. J. (2008). Why Are Students not Majoring in Information Systems. Journal of Information Systems Education, 19(1), 43-53.

Weis T. (2009). College Majors That Will Get You a Job. Forbes, January 26.

Word, J. (2009). VP of Product Strategy, SAP AG, December 14. 